\title{
THE MAY MEETING IN WASHINGTON
}

The three hundred seventy-ninth meeting of the American Mathematical Society was held at The George Washington University, Washington, D. C., on Friday and Saturday, May 2-3, 1941. The attendance was approximately two hundred fifty including the following one hundred eighty-two members of the Society:

C. R. Adams, R. P. Agnew, Leonidas Alaoglu, C. B. Allendoerfer, P. H. Anderson, H. A. Arnold, J. V. Atanasoff, Y. K. Bal, Alfred Basch, P. T. Bateman, P. G. Bergmann, E. E. Betz, G. D. Birkhoff, Archie Blake, R. P. Boas, H. F. Bohnenblust, T. A. Botts, D. G. Bourgin, S. G. Bourne, R. H. Bruck, R. S. Burington, E. W. Cannon, Abraham Charnes, A. B. Coble, I. S. Cohen, R. M. Cohn, J. B. Coleman, Richard Courant, W. H. H. Cowles, M. J. Cox, M. T. Curran, H. B. Curry, Tobias Dantzig, C. H. Dowker, Arnold Dresden, F. G. Dressel, R. F. Dressler, J. C. Durand, Samuel Eilenberg, Benjamin Epstein, Paul Erdös, F. A. Ficken, E. J. Finan, M. M. Flood, Tomlinson Fort, R. M. Foster, F. H. Fowler, K. O. Friedrichs, T. C. Fry, Abe Gelbart, J. H. Giese, M. A. Girshick, J. W. Givens, Michael Goldberg, H. S. Grant, J. A. Greenwood, T. N. E. Greville, D. W. Hall, N. A. Hall, P. R. Halmos, W. J. Harrington, G. A. Hedlund, M. H. Heins, Edward Helly, H. C. Hicks, Einar Hille, M. P. Hollcroft, T. R. Hollcroft, Witold Hurewicz, Nathan Jacobson, R. F. Johnson, F. E. Johnston, H. A. Jordan, Mark Kac, Shizuo Kakutani, J. H. Kenna, R. B. Kershner, B. F. Kimball, J. W. Kitchens, J. R. Kline, H. N. Laden, O. E. Lancaster, A. E. Landry, M. E. Layne, Solomon Lefschetz, Joseph Lehner, Marie Litzinger, E. R. Lorch, Eugene Lukacs, D. T. McClay, N. H. McCoy, E. J. McShane, J. K. L. MacDonald, C. C. MacDuffee, H. M. MacNeille, Dorothy Maharam, P. T. Maker, Dorothy Manning, M. H. Martin, F. M. Mears, Don Mittleman, Elizabeth Monroe, T. W. Moore, Marston Morse, F. D. Murnaghan, F. J. Murray, F. G. Myers, Yael Naim, K. L. Nielsen, Ivan Niven, F. W. Owens, H. B. Owens, J. C. Oxtoby, Gordon Pall, G. W. Patterson, Everett Pitcher, George Polya, H. A. Rademacher, Tibor Rado, C. J. Rees, R. G. D. Richardson, E. K. Ritter, H. E. Robbins, J. H. Roberts, H. P. Robertson, M. S. Robertson, L. B. Robinson, W. J. Robinson, J. B. Rosser, Raphaël Salem, S. A. Schelkunoff, Ivor Schilansky, Abraham Schwartz, W. M. Scott, I. E. Segal, Abraham Seidenberg, I. M. Sheffer, Seymour Sherman, J. A. Shohat, Abraham Sinkov, M. F. Smiley, T. L. Smith, Virgil Snyder, V. E. Spencer, J. J. Stoker, M. H. Stone, J. D. Tamarkin, A. H. Taub, J. H. Taylor, B. J. Tepping, M. E. Terry, J. M. Thompson, C. J. Thorne, R. M. Thrall, E. W. Titt, C. B. Tompkins, W. R. Transue, W. J. Trjitzinsky, J. W. Tukey, J. H. Van Vleck, Oswald Veblen, T. L. Wade, G. L. Walker, A. D. Wallace, Henry Wallman, G. C. Webber, F. M. Weida, C. H. Wheeler, P. A. White, A. L. Whiteman, G. T. Whyburn, Norbert Wiener, J. D. Williams, M. H. Williams, W. L. G. Williams, John Williamson, H. A. Wood, D. W. Woodard, J. W. Wrench, J. W. T. S. Youngs, Oscar Zariski, Antoni Zygmund.

The meeting opened Friday morning in two sections, Analysis, Professor Tibor Radó presiding, and Algebra and Geometry, Professor Gordon Pall and Dr. R. M. Thrall presiding.

Two general sessions were held Friday afternoon. At the first, Vice

President F. D. Murnaghan presiding, Professor F. J. Murray of 
Columbia University gave an address entitled The analysis of linear transformations. The second, Professor A. B. Coble presiding, was for short papers on various subjects.

On Saturday morning at a general session, Professor J. A. Shohat presiding, Professor I. M. Sheffer of The Pennsylvania State College gave an address entitled Some applications of certain polynomial classes. This was followed by two sections, Algebra and Topology, Professor C. C. MacDuffee presiding, and Probability, Statistics, Applied Mathematics, Professor Norbert Wiener presiding.

Saturday afternoon was devoted to a symposium on the RayleighRitz method and its applications, at which President Marston Morse presided. The following addresses were given: Variational methods for the solution of boundary value problems by Professor Richard Courant of New York University; Engineering applications of the RayleighRitz method by Professor J. P. Den Hartog of Harvard University; Applications of the Rayleigh-Ritz method in the theory of the structure of matter by Professor H. M. James of Purdue University. The discussion was led by Professor J. H. Van Vleck of Harvard University and Professor P. M. Morse of Massachusetts Institute of Technology.

All sessions were held in the Hall of Government of The George Washington University.

On Friday afternoon tea was served at Columbian House.

The dinner Friday evening at the Cosmos Club was attended by one hundred thirty members and guests. The toastmaster, Professor C. R. Adams, introduced three speakers, Professor R. W. Bolwell, Chairman of the Graduate Council of The George Washington University, and Professors C. C. MacDuffee and H. P. Robertson.

At the beginning of the symposium Saturday afternoon Professor Gordon Pall presented a resolution expressing the appreciation and thanks of the Society to The George Washington University, the members of the local committee, and all others concerned for the excellent arrangements for the meeting. The resolution was unanimously adopted by a rising vote.

The Council met at 9:00 P.M., Friday, May 2, in the Holmes Room of the Cosmos Club.

The Secretary announced the election of the following fifty-nine persons to membership in the Society:

Mr. Milton Abramowitz, Brooklyn, N. Y.;

Miss Grace Karen Anderson, American Mathematical Society, New York, N. Y.;

Professor Tomás R. Bachiller, University of Madrid, Madrid, Spain;

Mr. Yusuf Kenan Bal, Columbia University; 
Mr. James Douglas Bankier, Rice Institute;

Mr. Paul Trevier Bateman, University of Pennsylvania;

Professor Maurice Anthony Biot, Columbia University;

Professor Juan Blaquier, University of Buenos Aires, Buenos Aires, Argentina;

Professor Clotilde Bula, University of Rosario, Rosario, Argentina;

Mr. Philip Staats Carter, R.C.A. Communications Inc., Rocky Point, L. I., N. Y.;

Mr. Leo Cohen, Columbia University;

Mr. Charles Raymond DePrima, New York University;

Dr. Henry Chabot Dieckmann, Occidental College, Los Angeles, Calif.;

Dean Margaret Criswell Disert, Wilson College, Chambersburg, Pa.;

Mr. Robert Franklin Dressler, University of Pennsylvania;

Professor William Maurice Ewing, Lehigh University;

Mr. W. Eugene Ferguson, University of Missouri;

Professor Fernando L. Gaspar, University of Rosario, Rosario, Argentina;

Dr. John H. Giese, Rutgers University;

Dr. Basil E. Gillam, University of Missouri;

Mr. Thomas Franklin Glass, Rice Institute;

Dean John Alonzo Goff, Towne Scientific School, University of Pennsylvania;

Mr. Richard Albert Good, University of Wisconsin;

Mr. Lewis Greenwald, New York Evening High School;

Mr. Eli Grossman, United States Life Insurance Co., New York, N. Y.;

Professor Emil J. Gumbel, New School for Social Research, New York, N. Y.;

Professor Harrod Harold Hartzler, Goshen College, Goshen, Ind.;

Professor Clifton T. Hazard, Purdue University;

Dr. Aaron Paul Horst, Procter and Gamble Co., Cincinnati, Ohio;

Dr. Colin Munroe Hudson, Frankford Arsenal, Philadelphia;

Dr. Leroy Charles Hutchinson, Michigan College of Mining and Technology, Houghton, Mich.;

Professor Ralph William Jones, University of Delaware;

Major Paul Hanes Kemmer, Chief Aircraft Laboratory, Wright Field, Dayton, Ohio;

Dr. John Maurice Kingston, University of Washington;

Mr. Joseph Landin, New York University;

Miss Jeanne Starrett Le Caine, Cambridge, Mass.;

Mr. Max LeLeiko, Willard Contracting Corporation, New York, N. Y.;

Dr. Eugene Lukacs, Baltimore, Md.;

Dr. Rudolf Luneburg, Spencer Lens Company, Buffalo, N. Y.;

Dr. Szolem Mandelbrojt, Rice Institute;

Dr. Warren Perry Mason, Bell Telephone Laboratories, New York, N. Y.;

Dr. William Alvin Mersman, University of California, College of Agriculture;

Mr. Osborn Maitland Miller, American Geographical Society, New York, N. Y.;

Mr. Olen Alvin Nance, University of Missouri;

Dr. William Donald Phelps, R.C.A. Manufacturing Co., Camden, N. J.;

Mr. Harry Pollard, Dorchester, Mass.;

Dr. Virgil Nelson Robinson, Louisiana State University;

Professor Frederick William Rogers, University of Cincinnati;

Mr. Jerome Colbert Smith, University of Pennsylvania;

Dr. Ernst Snapper, Princeton University;

Mr. Herbert Solomon, Columbia University;

Dr. Thomas H. Southard, Wayne University; 
Mr. Wolfgang Joseph Thron, Rice Institute;

Dr. Philip Russell Wallace, University of Cincinnati;

Mr. Edward Faith White, University of Cincinnati;

Mr. Albert Wiesenberg, Columbia University;

Mr. Herbert Wolfe, Brooklyn College (Evening Session);

Mr. Richard Schuyler Wolfe, Great Falls Commercial College, Great Falls, Mont.;

Mr. Max A. Woodbury, University of Michigan.

It was reported that the following had been elected as nominees on the Institutional Memberships of the institutions indicated:

University of Chicago: Messrs. William Caswell Carter, Gerhard Karl Kalisch, and Richard Donald Schafer, and Miss Alice Elizabeth Turner.

Lehigh University: Mr. Leonard Pattillo Burton.

Metropolitan Life Insurance Company: Messrs. Malvin E. Davis and James Russell Herman.

Syracuse University: Mr. William John Strange.

Wayne University: Mr. Clifford Raymond Simms.

Wesleyan University: Messrs. Francis Escott and Joseph Wannemacher.

The following appointments by President Marston Morse were reported: as a standing Committee on Places of Meetings, Professors A. B. Coble (chairman), 3 years, W. B. Carver, 2 years, and E. J. McShane, 1 year; as auditors of the Society's books for 1941, Professors R. G. Archibald and A. E. Meder, Jr.; as an additional member of the Committee on Arrangements for the Annual Meeting of 1941, Professor W. D. Cairns; as Committee on Arrangements for the Summer Meeting of 1942 at Cornell University, Professors R. P. Agnew (chairman), W. D. Cairns, A. D. Campbell, T. R. Hollcroft, J. B. Rosser, R. J. Walker; as chairman of the Nominating Committee, to replace Professor G. A. Bliss, Professor A. B. Coble; as representative of the Society at the inauguration of Victor Raymond Edman as fourth President of Wheaton College, Wheaton, Illinois, on May 9, 1941, Professor L. M. Graves; as representative of the Society at the inauguration of Virgil Melvin Hancher as President of The State University of Iowa on May 24, 1941, Professor R. B. McClenon; as representative of the Society at the Fiftieth Anniversary Celebration of the University of Chicago on September 27, 28, and 29, 1941, Professor D. R. Curtiss. It was also reported that President Marston Morse will represent the Society at the Centenary Celebration of Fordham University on September 15-17, 1941.

The dates for the Annual Meeting of 1941 at Lehigh University were set as December 29-31, 1941.

The Secretary reported that Professor E. J. McShane had accepted the invitation to deliver the Colloquium Lectures at the Summer 
Meeting of 1943 ; his subject will be Existence theorems in the calculus of variations.

The Secretary reported that the following had been chosen as the voting representatives on the Council of the editorial committees for the year 1941: Bulletin-Dean Tomlinson Fort; Transactions-Professor C. C. MacDuffee; Colloquium-Professor J. D. Tamarkin; American Journal of Mathematics-Professor T. H. Hildebrandt.

The Secretary reported that an unrestricted gift of $\$ 1,000$ had been received from Dr. Robert Henderson. The following resolution was unanimously adopted and copies were ordered spread upon the records and sent to Dr. Henderson:

The Council of the American Mathematical Society expresses its deep gratitude to Dr. Robert Henderson for his generous gift of $\$ 1,000$ to the Society. It also wishes at this time to make grateful acknowledgment of his many years of faithful service on the Board of Trustees where his wise counsel has been invaluable. We recognize these acts as the natural expression of a life devoted to the study and application of mathematics.

It was announced that Professor Oscar Zariski had been elected as a member of the Transactions Editorial Committee to fill the unexpired term of the late Professor W. C. Graustein. Professor Hille reported that Professors Nelson Dunford and R. L. Wilder had been appointed Associate Editors.

Professors J. L. Walsh (chairman), E. W. Chittenden, and E. J. McShane were appointed as a committee to confer with the Williams and Wilkins Company on an agreement concerning the proposed new series of monographs for which the name Mathematical Surveys has been suggested. The Council had previously voted to approve the memorandum submitted by the Company in which the introduction of this series was suggested.

Titles and cross references to the abstracts of the papers read follow below. Papers whose abstract numbers are followed by the letter $t$ were read by title. The papers numbered 1 to 11 were read before the section for Analysis; those numbered 12 to 22 before the section for Algebra and Geometry; those numbered 23 to 27 before the general session on Friday afternoon; those numbered 28 to 34 before the section for Algebra and Topology; those numbered 35 to 41 before the section for Probability, Statistics, Applied Mathematics; those numbered 42 to 67 were read by title. Paper 8 was read by Mr. Harrington, paper 14 by Dr. Smiley, paper 17 by Dr. Bruck, paper 18 
by Professor Wade, paper 27 by Professor Polya, and paper 38 by Mr. Thorne. Dr. Bergman was introduced by Dr. D. C. Spencer, Mr. Gravalos by Professor G. D. Birkhoff, Professor Sutton by Professor C. B. Allendoerfer, Dr. Weinstein by Dr. H. E. Robbins, Dr. Bers by Dr. Abe Gelbart.

1. Joseph Lehner: A partition function connected with the modulus five. (Abstract 47-7-298.)

2. Stefan Bergman: The method of the minimum integral and the analytic continuation of functions. (Abstract 47-5-217.)

3. K. L. Nielsen: Concerning boundary value problems for linear differential equations when the boundary conditions are given by Stieltjes integrals. (Abstract 47-5-236.)

4. E. J. McShane: Sufficient conditions for a weak relative minimum in the problem of Bolza. (Abstract 47-7-309.)

5. F. A. Ficken: Certain systems of subsets of quasi and partially ordered sets. (Abstract 47-7-328.)

6. E. R. Lorch: The spectrum of linear transformations. (Abstract 47-5-235.)

7. W. J. Trjitzinsky: Singular Lebesgue-Stieltjes integral equations. (Abstract 47-7-316.)

8. W. J. Harrington and J. B. Rosser: $A$ study of certain functions auxiliary to Brun's method in number theory. (Abstract 47-5-225.)

9. D. G. Bourgin: On reflexive Banach spaces. (Abstract 47-7-304.)

10. M. H. Heins: A generalization of the Aumann-Carathéodory "Starrheitssatz." (Abstract 47-7-306.)

11. Raphaël Salem: On trigonometrical series whose coefficients do not tend to zero. (Abstract 47-5-243.)

12. W. M. Scott: On matrix algebras over an algebraically closed field. (Abstract 47-5-198.)

13. R. M. Thrall: On Young's semi-normal representation of the symmetric group. (Abstract 47-5-204.)

14. Everett Pitcher and M. F. Smiley: Transitivities of betweenness. (Abstract 47-5-196.)

15. Gordon Pall: The construction of positive ternary quadratic forms. (Abstract 47-3-174.)

16. D. T. McClay: Clifford numbers. (Abstract 47-7-322.)

17. R. H. Bruck and T. L. Wade: Bisymmetric tensor algebra. I. (Abstract 47-5-184.)

18. R. H. Bruck and T. L. Wade: Bisymmetric tensor algebra. II. (Abstract 47-5-185.)

19. Y. K. Bal: Study on graphs. Preliminary report. (Abstract 475-262.) 
20. F. G. Gravalos: The algebraic integrals of Hill's equations. (Abstract 47-7-318.)

21. J. B. Rosser: A generalization of the euclidean algorithm to several dimensions. (Abstract 47-7-299.)

22. Mark Kac: Remark on the distribution of values of the arithmetic function $d(m)$. (Abstract 47-7-297.)

23. Tibor Radó: On convergence in length and convergence in area. (Abstract 47-5-239.)

24. J. A. Shohat: On the best polynomial approximation for functions possessing derivatives. (Abstract 47-5-249.)

25. C. C. MacDuffee: Products and norms of ideals. (Abstract 475-188.)

26. G. T. Whyburn: Orbit decompositions. (Abstract 47-5-291.)

27. George Polya and Norbert Wiener: On the oscillation of the derivatives of a periodic function. (Abstract 47-7-312.)

28. G. L. Walker: The elementary divisors of a direct product of matrices. (Abstract 47-5-205.)

29. H. A. Arnold: Homology in set-intersections, with an application to $r$-regular convergence. (Abstract 47-7-325.)

30. I. M. Niven: Equations in quaternions. (Abstract 47-5-192.)

31. A. D. Wallace: A fixed-point theorem for trees. (Abstract 475-287.)

32. Samuel Eilenberg: Banach space methods in topology. II. (Abstract 47-5-279.)

33. P. A. White: A decomposition of true cyclic elements by means of continua. (Abstract 47-5-288.)

34. Witold Hurewicz: On duality theorems. (Abstract 47-7-329.)

35. Alfred Basch: A contribution to the theory of multiple correlation. (Abstract 47-7-324.)

36. J. A. Greenwood: $A$ theorem on probability assignments to events. (Abstract 47-5-271.)

37. K. O. Friedrichs: On the mathematical theory of the buckling of spherical shells. (Abstract 47-7-317.)

38. C. J. Thorne and J. V. Atanasoff: The application of a general functional approximation method to thin plate problems. (Abstract 475-259.)

39. R. M. Sutton: An instrument for drawing confocal conics. (Abstract 47-5-258.)

40. Alexander Weinstein: On the vibrations of a clamped plate under tension. (Abstract 47-5-260.)

41. Richard Courant: On a new type of variational problems, with physical demonstrations. (Abstract 47-5-220.) 
42. R. P. Agnew: On limits of integrals. (Abstract 47-7-301-t.)

43. H. A. Arnold: On r-regular convergence of sets. (Abstract 47-7326-t.)

44. Stefan Bergman: A method for summation of series of orthogonal functions of two variables. (Abstract 47-7-302-t.)

45. Lipman Bers: On a generalized harmonic measure. (Abstract 47-5-218-t.)

46. Leonard Carlitz: Some interpolation formulas connected with polynomials in $G F\left(p^{n}\right)$. (Abstract 47-5-210-t.)

47. Leonard Carlitz: The coefficients of the reciprocal of certain series. (Abstract 47-5-211-t.)

48. Leonard Carlitz: An analogue of the Bernoulli polynomials. (Abstract 47-7-296-t.)

49. A. H. Clifford: Matrix representations of completely simple semigroups. (Abstract 47-7-293-t.)

50. A. H. Copeland: If. (Abstract 47-5-268-t.)

51. J. J. DeCicco: Equilong geometry of differential equations of first order. (Abstract 47-3-151-t.)

52. Samuel Eilenberg: Irreducible transformations onto manifolds. (Abstract 47-5-280-t.)

53. G. E. Forsythe: Cesàro summability of random variables. (Abstract 47-5-270-t.)

54. Einar Hille: Notes on linear transformations. III. Semi-groups on Lebesgue spaces. (Abstract 47-7-307-t.)

55. C. T. Hsu: Two samples from normal bivariate populations. (Abstract 47-5-273-t.)

56. L. H. Loomis: A simple proof of the Fatou theorem. (Abstract 47-5-234-t.)

57. L. H. Loomis: A converse to the Fatou theorem. (Abstract 47-5233-t.)

58. Saunders MacLane and O. F. G. Schilling: A formula for the direct product of cross product algebras. (Abstract 47-5-189-t.)

59. Saunders MacLane and O. F. G. Schilling: Group extensions characterizing complete fields. (Abstract 47-5-190-t.)

60. Saunders MacLane and O. F. G. Schilling: The principal divisor theorem for function fields. (Abstract 47-5-191-t.)

61. H. J. Riblet: Certain theorems for symmetric differential functions. (Abstract 47-5-197-t.)

62. M. S. Robertson: The partial sums of multivalently star-like functions. (Abstract 47-7-314-t.)

63. L. B. Robinson: Some complete systems of semitensors. (Abstract 47-7-315-t.) 
64. Raphaël Salem: On some properties of symmetrical perfect sets. (Abstract 47-5-242-t.)

65. Louis Weisner: Polynomials whose roots lie in a sector. (Abstract 47-5-207-t.)

66. G. T. Whyburn: Almost periodicity. (Abstract 47-5-290-t.)

67. G. T. Whyburn: Regular almost periodicity. (Abstract 47-5292-t.)

T. R. Hollcroft, Associate Secretary 